\title{
Systematic Literature Review of Knowledge Management Strategy for Optimization Budgeting Function on Indonesian Local Legislative Council
}

\author{
Assistriadi Widjiseno Anis Eliyana \\ Faculty Of Ecomomics And Business, Airlangga University
}

\begin{abstract}
Purpose - Legislative elections will be held in Indonesia on April 17th, 2019 and will be to elect 17.610 members of local legislative council. Local legislative council members should be oriented towards promoting budgets that encourage public welfare, should have the necessary knowledge to make appropriate budget allocation proposals for the key areas of healthcare, education and local economic development, and should have the analytical skills necessary to provide meaningful critical input to local budget development, and to monitor budget implementation. Currently based on some prior literature studies, no knowledge management strategy on the local legislative council to discovering, capturing, sharing, maintaining knowledge and there will be knowledge loss from going to retire senior local legislative council members who have the valuable knowledge and experiences. To address these challenges, Indonesian local legislative council urgency to develop knowledge management strategy. Methodology - Systematic literature reviews (SLR) start with formulation of (RQ) research questions focus on 5 elements known as PICOC and then search relevant studies, select relevant studies, assess studies' quality, perform data extraction, perform synthesis of evidence.Findings - The authors propose that knowledge management strategy on Indonesian local legislative council that can be determine such as increasing the coordination effectiveness of program planning and budgeting as to increase the accountability of the organization.Originality/value contributions - This paper makes contributions to extends the knowledge management strategy to local government public budget management.
\end{abstract}

Keywords : Knowledge Management, Strategy, Budget Function, Local Legislative Council

DOI: $10.7176 / \mathrm{IKM} / 9-4-04$

Publication date: April $30^{\text {th }} 2019$

\section{Introduction}

Knowledge management can be defined as performing the activities involved in discovering, capturing, sharing, and applying knowledge so as to enhance, in a cost-effective fashion, the impact of knowledge on the unit's goal achievement[2]. According to some research knowledge management (KM) can bridge the knowledge gap within people and organization [1]. Knowledge Management (KM) processes play a significant role in the implementation of various Information Systems [15]. Knowledge management is an effort to improve the ability of the organization in managing intellectual, The goal of course is to harness the assets to reach organisational performance better to speed up the achievement of a goal the implementation of the bureaucratic reform[3]. Management knowledge play an important role in helping to improve organisational performance.This is in line with one of the objectives of the bureaucratic reform.Management knowledge increase the effectiveness of because it can encourage the use of knowledge they have ( knowledge reuse ) to improve the quality of the decision making process[3]. Knowledge management can serve as tools in the process of change and transformation organization, knowledge management can help develop the cultural learning in an organization[3]. Data and Information of Indonesia's genetic resources in research institutions and traditional knowledge in today's society have not been managed effectively. The data and information are still scattered in research institutes and societies, so that if there is no action of integrated management, the data and information will be lost[4]. There were 4 (four) knowledge management strategies that can be determine such as increasing the coordination effectiveness of program planning and budgeting as to increase the accountability of the organization, performance achievement and organizational performance, raise up a team work culture within organization to reach organizational performance and competitive advantage[5]. Knowledge-based company should consider to keep valuable intellectual capital from its knowledge workers. If not, the company can lose its competitive advantages to face todays business challenges because it does not have the power and knowledge necessary as the driver to develop or create business value. KM provides the solution for managing the knowledge in the company systematically and effectively[6]. Knowledge Management activities in government institution and it can be a reference for another government human capital management division to implement $\mathrm{KM}[8]$. Based on some literature studies conducted in this research, the author supposed a theoretical model of Indonesian knowledge management model that consist of two stages defining organizational strategy and knowledge management strategy. Each stage consist of some substantial element, for organizational strategy there are two element organizational vision and mission that align with business strategy. In Knowledge 
management strategy stages consist of four elements there are organization culture, critical success factor of knowledge management, define organization KM process and assessment of organization knowledge mapping. The last one is government policy that used to regulate and restrict the model[9]. The gap between existing condition of KM implementation and the roadmap can be a recommendation for the government to construct a problem solution of each gap. They also can make a regulation or policy related to the knowledge management and the process of government human capital management which align with the bureaucratic reform program[10]. Research finding that Government Human Capital Knowledge Management of Republic Indonesia (NUSANTARA) model consists of eight layers there are vision and mission, CSF, knowledge mechanism and technologies, KMS, KM cycle, KM process, organizational core knowledge and government public services. The NUSANTARA model can be implemented in KEMENPAN \& RB, LAN and BKN for supporting the government human capital management process and to achieve the bureaucratic reform objectives in develop the professional government human capital[11]. The issue of knowledge management in the public sector offers several avenues for future research. One of the most interesting and important questions relates to the implementation and operationalization of knowledge management as a part of the general management system and the creation of a culture of knowledge-based management[12]. One of problem that arises when conducting an analysis to determine ideal proportion of local budget allocations prioritized for public services improvement and economic fulfillment, social, and cultural rights of the people in City's/Regency's APBD document is data size and information that should be processed, budget data complexity structure as well as information allocation presentation format and limited budget distribution. Therefore, it is necessary to have information technology support as its solution, in which this information technology has been tested has capability and reliability in processing and utilizing available data in large volume, fast, and various[13]. The findings show that human capital is the primary component of knowledge assets. It is up to organizations to prosper with the development and acquisition of knowledge from external sources, as distinct as, customers, suppliers, labor market and environment, among others[14].

\section{Methodology}

A systematic approach for reviewing the literature on the local government knowledge management strategy is chosen. Systematic literature reviews (SLR) is a process of identifying, assessing, and interpreting all available research evidence, to provide answers for a particular research question (Kitchenham et al., 2007). Systematic literature reviews (SLR) is performed in three stages: planning, conducting and reporting the literature review.
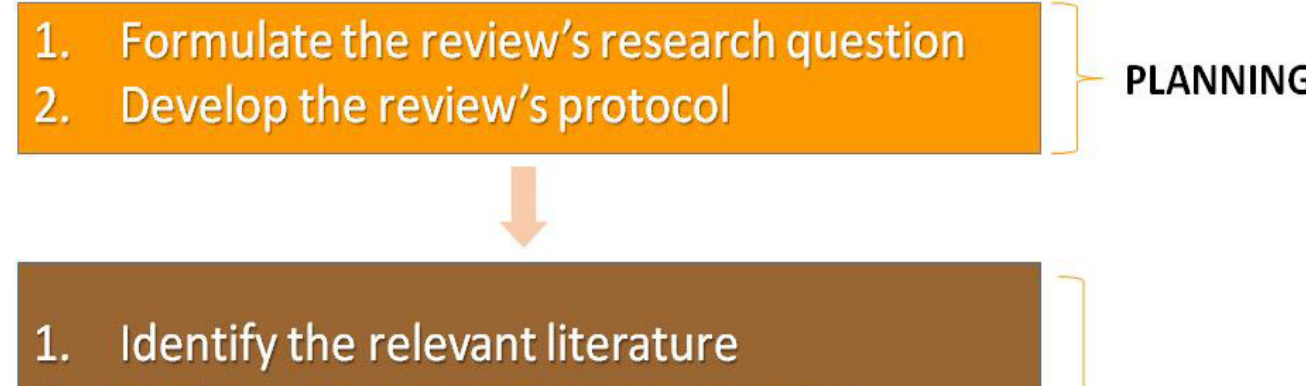

2. Perform selection of primary studies

3. Perform data extraction

4. Assess studies' quality

5. Conduct synthesis of evidence

\section{CONDUCTING}

\section{Write up the SLR report/paper}

\section{REPORTING}

Figure 1 Systematic Literature Review Steps

and the motivations for using systematic literature reviews (SLR) is

a) to systematically accumulate, organize, evaluate, and synthesize all existing research evidence of your research area. 
b) to present fair evaluation of a research topic by using a trustworthy, rigorous, and auditable methodology.

c) to produce reliable and unbiased results. And to identify gaps in the existing research that will lead to topics for further investigation.

d) to provide as a background to position new research activities. And to support Evidence-based research.

The first phase of this systematic literature reviews (SLR) is formulation of research questions (RQ) is used to guide the search process and to guide the extraction process. The research questions (RQ) will identify discrepancies between commonly held beliefs and the reality. Petticrew \& Robert (2006) suggest that the formulation of research questions (RQ) about effectiveness of a treatment should focus on 5 elements known as PICOC: Population (P) - the target group for the investigation (e.g. people, software etc.). Intervention (I) specifies the investigation aspects or issues of interest to the researcher(s). Comparison (C) - aspect of the investigation with which the intervention is being compared to. Outcomes $(\mathrm{O})$ - the effect of the intervention. Context $(\mathrm{C})$ - the setting or environment of the investigation.

Table 1 Summary of PICOC

\begin{tabular}{|l|l|}
\hline Population (P) & Indonesian Local Legislative Council \\
\hline Intervention (I) & Knowledge Management Strategy \\
\hline Comparison (C) & n/a \\
\hline Outcomes (O) & Successful optimalize budgeting function on Indonesian local legislative council \\
\hline Context (C) & Studies in Indonesian Local Government and academia \\
\hline
\end{tabular}

Table 2 Research Questions on Literature Review

\begin{tabular}{|c|l|l|}
\hline ID & \multicolumn{1}{|c|}{ Research Question } & \multicolumn{1}{c|}{ Motivation } \\
\hline RQ1 & $\begin{array}{l}\text { Which journal is the most significant local } \\
\text { government knowledge management } \\
\text { strategy? }\end{array}$ & $\begin{array}{l}\text { Identify the most significant journals in the local } \\
\text { government knowledge management strategy field }\end{array}$ \\
\hline RQ2 & $\begin{array}{l}\text { Who are the most active and influential } \\
\text { researchers in the local government } \\
\text { knowledge management strategy field? }\end{array}$ & $\begin{array}{l}\text { Identify the most active and influential researchers } \\
\text { who contributed so much on a research area of local } \\
\text { government knowledge management strategy }\end{array}$ \\
\hline RQ3 & $\begin{array}{l}\text { What kind of research topics are selected by } \\
\text { researchers in the local government } \\
\text { knowledge management strategy field? }\end{array}$ & $\begin{array}{l}\text { Identify research topics and trends in local } \\
\text { government knowledge management strategy }\end{array}$ \\
\hline RQ4 & $\begin{array}{l}\text { What kind of methods are used for local } \\
\text { government knowledge management } \\
\text { strategy? }\end{array}$ & $\begin{array}{l}\text { Identify opportunities and trends for local } \\
\text { government knowledge management strategy } \\
\text { method }\end{array}$ \\
\hline RQ5 & $\begin{array}{l}\text { What kind of methods are used most often } \\
\text { for local government knowledge } \\
\text { management strategy? }\end{array}$ & $\begin{array}{l}\text { Identify the most used methods for local government } \\
\text { knowledge management strategy }\end{array}$ \\
\hline RQ6 & $\begin{array}{l}\text { Which method performs best when used for } \\
\text { local government knowledge management } \\
\text { strategy? }\end{array}$ & $\begin{array}{l}\text { Identify the best method in local government } \\
\text { knowledge management strategy }\end{array}$ \\
\hline RQ7 & $\begin{array}{l}\text { What kind of method improvements are } \\
\text { proposed for local government knowledge } \\
\text { management strategy? }\end{array}$ & $\begin{array}{l}\text { Identify the proposed method improvements for } \\
\text { predicting the local government knowledge } \\
\text { management strategy }\end{array}$ \\
\hline
\end{tabular}

And the next phase is conducting review that consist of some activities, such as 1) searching relevant studies that involves a comprehensive and exhaustive searching of studies to be included in the review, define a search strategy and search strategies are usually iterative and benefit from preliminary searches (to identify existing review and volume of studies), (Zhang et al. (2011) suggest focus with 4 element Which approach to be used in search process (e.g., manual or automated search), Where (venues or databases) to search, and which part of article (field) should be searched, What (subject, evidence type) to be searched, and what are queries (search strings) fed into search engines, and When is the search carried out, and what time span to be searched. 2) Selection of studies primary studies need to be assessed for their actual relevance and set the criteria for including or excluding studies, and inclusion \& exclusion criteria should be based on RQ. 3) Assessing studies' quality having Reasons to provide more detailed Inclusion/Exclusion criteria. And to guide the interpretation of findings and determine the strength of inferences. And to guide recommendations for further research. 4) Data Extraction is collect all the information that can be used to answer the RQ and the study's quality criteria. The selected primary studies are extracted to collect the data that contribute to addressing the research questions concerned in this review. 5) Synthesis of evidence is to analyze and evaluate multiple studies and select appropriate methods. The goal of data synthesis is to aggregate evidence from the selected studies for answering 
the research questions.

3. Findings

\begin{tabular}{|c|c|c|c|c|c|}
\hline Source & $\begin{array}{c}\text { Study } \\
\text { Purpose }\end{array}$ & Methods & Country & Participant & Findings \\
\hline $\begin{array}{c}\text { Dana Indra } \\
\text { Sensuse, } \\
\text { Lukman, } 2012\end{array}$ & $\begin{array}{l}\text { Knowledge } \\
\text { Management } \\
\text { Model And } \\
\text { Strategy }\end{array}$ & $\begin{array}{l}\text { Interviews } \\
\text { And Survey }\end{array}$ & Indonesia & Steakholders & $\begin{array}{l}\text { Data and Information of } \\
\text { Indonesia's genetic resources in } \\
\text { research institutions and } \\
\text { traditional knowledge in today's } \\
\text { society have not been managed } \\
\text { effectively. The data and } \\
\text { information are still scattered in } \\
\text { research institutes and societies, } \\
\text { so that if there is no action of } \\
\text { integrated management, the data } \\
\text { and information will } \\
\text { be lost. Therefore, it is necessary } \\
\text { to develop a knowledge } \\
\text { management model of genetic } \\
\text { resources and traditional } \\
\text { knowledge in Indonesia that will } \\
\text { hold, process and integrate } \\
\text { genetic resources, so that they } \\
\text { can be identified, mapped and } \\
\text { accessed by the public. }\end{array}$ \\
\hline $\begin{array}{c}\text { Elin } \\
\text { Cahyaningsih, } \\
\text { Dieny } \\
\text { Sukmiati, Nur } \\
\text { Chasanah, } \\
\text { Dana Indra } \\
\text { Sensuse, } 2013\end{array}$ & $\begin{array}{c}\text { Knowledge } \\
\text { Management } \\
\text { Strategy }\end{array}$ & $\begin{array}{c}\text { Balanced } \\
\text { Scorecard } \\
\text { Survey }\end{array}$ & Indonesia & $\begin{array}{c}\text { Head office } \\
\text { Of badan } \\
\text { kepegawaian } \\
\text { negara, jakarta }\end{array}$ & $\begin{array}{l}\text { There were } 4 \text { (four) knowledge } \\
\text { management strategies that can } \\
\text { be determine such as increasing } \\
\text { the coordination effectiveness of } \\
\text { program planning and budgeting } \\
\text { as to increase the accountability } \\
\text { of the organization, performance } \\
\text { achievement and organizational } \\
\text { performance, raise up a team } \\
\text { work culture within organization } \\
\text { to reach organizational } \\
\text { performance and competitive } \\
\text { advantage, monitoring program } \\
\text { performance in order to create a } \\
\text { working relationship and good } \\
\text { personnel management for } \\
\text { increasing organizational } \\
\text { performance and increasing } \\
\text { timeliness of service target } \\
\text { achievement and standard time of } \\
\text { customer service in order to } \\
\text { increase organizational } \\
\text { performance. }\end{array}$ \\
\hline $\begin{array}{c}\text { Dana Indra } \\
\text { Sensuse, } \\
\text { Wahyu Catur } \\
\text { Wibowo, Elin } \\
\text { Cahyaningsih, } \\
2016\end{array}$ & $\begin{array}{c}\text { Knowledge } \\
\text { Management } \\
\text { Model }\end{array}$ & $\begin{array}{l}\text { Qualitative } \\
\text { Study }\end{array}$ & Indonesia & Not specified & $\begin{array}{l}\text { A theoretical model of } \\
\text { Indonesian knowledge } \\
\text { management model that consist } \\
\text { of two stages defining } \\
\text { organizational strategy And } \\
\text { knowledge management strategy. } \\
\text { Each stage consist of some } \\
\text { substantial element, for } \\
\text { organizational } \\
\text { Strategy there are two element } \\
\text { organizational vision and mission }\end{array}$ \\
\hline
\end{tabular}




\begin{tabular}{|c|c|c|c|c|c|}
\hline & & & & & that align with business strategy \\
\hline $\begin{array}{c}\text { Elin } \\
\text { Cahyaningsih, } \\
\text { Dana Indra } \\
\text { Sensusea, } \\
\text { Handrie } \\
\text { Noprisson, } \\
2017\end{array}$ & $\begin{array}{c}\text { Knowledge } \\
\text { Management } \\
\text { Strategy }\end{array}$ & $\begin{array}{l}\text { Literature } \\
\text { study, data } \\
\text { collection, } \\
\text { determining } \\
\text { the strategy } \\
\text { matrix } \\
\text { using OCAI } \\
\text { and Gap } \\
\text { Analysis }\end{array}$ & Indonesia & $\begin{array}{l}\text { State Ministry } \\
\text { for State } \\
\text { Apparatus } \\
\text { Reform } \\
\text { (KEMENPAN } \\
\text { \& RB), } \\
\text { National Civil } \\
\text { Service } \\
\text { Agencies } \\
\text { (BKN) and } \\
\text { National } \\
\text { Institute of } \\
\text { Public } \\
\text { Administration } \\
\text { (LAN). }\end{array}$ & $\begin{array}{l}\text { Research finding that KM } \\
\text { strategy roadmap of government } \\
\text { human capital management } \\
\text { consists of three criteria there are } \\
\text { people, process and technology. } \\
\text { The roadmap timeline divides } \\
\text { into three phases which have } \\
\text { several activities on it. The KM } \\
\text { strategy roadmap can be used for } \\
\text { the guidelines to the ministries } \\
\text { that assign to manage the } \\
\text { government human capital there } \\
\text { are KEMENPAN \& RB, LAN } \\
\text { and BKN }\end{array}$ \\
\hline $\begin{array}{c}\text { Elin } \\
\text { Cahyaningsih, } \\
\text { Dana Indra } \\
\text { Sensuse, } \\
\text { Aniati Murni } \\
\text { Arymurthy, } \\
\text { Wahyu Catur } \\
\text { Wibowo, } \\
2017\end{array}$ & $\begin{array}{c}\text { Knowledge } \\
\text { Management } \\
\text { Model }\end{array}$ & $\begin{array}{l}\text { Identify the } \\
\text { strategic } \\
\text { issue, } \\
\text { develop the } \\
\text { theoretical } \\
\text { model, } \\
\text { evaluate the } \\
\text { theoretical } \\
\text { model, } \\
\text { identify the } \\
\text { element } \\
\text { model and } \\
\text { knowledge } \\
\text { and the last } \\
\text { develop the } \\
\text { model }\end{array}$ & Indonesia & $\begin{array}{l}\text { State Ministry } \\
\text { for State } \\
\text { Apparatus } \\
\text { Reform } \\
\text { (KEMENPAN } \\
\text { \& RB), } \\
\text { National Civil } \\
\text { Service } \\
\text { Agencies } \\
\text { (BKN) and } \\
\text { National } \\
\text { Institute of } \\
\text { Public } \\
\text { Administration } \\
\text { (LAN). }\end{array}$ & $\begin{array}{l}\text { Research finding that } \\
\text { Government Human Capital } \\
\text { Knowledge Management of } \\
\text { Republic Indonesia } \\
\text { (NUSANTARA) model consists } \\
\text { of eight layers there are vision } \\
\text { and mission, CSF, knowledge } \\
\text { mechanism and technologies, } \\
\text { KMS, KM cycle, KM process, } \\
\text { organizational core knowledge } \\
\text { and government public services. } \\
\text { The NUSANTARA model can be } \\
\text { implemented in KEMENPAN \& } \\
\text { RB, LAN and BKN for } \\
\text { supporting the government } \\
\text { human capital management } \\
\text { process and to achieve the } \\
\text { bureaucratic reform objectives in } \\
\text { develop the professional } \\
\text { government human capital }\end{array}$ \\
\hline $\begin{array}{c}\text { Ana Isabel } \\
\text { Torres, } \\
\text { Silvana } \\
\text { Santos Ferraz, } \\
\text { Helena } \\
\text { Santos- } \\
\text { Rodrigues, } \\
2018\end{array}$ & $\begin{array}{c}\text { Knowledge } \\
\text { Management } \\
\text { Strategy }\end{array}$ & $\begin{array}{c}\text { Empirical } \\
\text { study } \\
\text { Empirical } \\
\text { methods } \\
\text { and data } \\
\text { Empirical } \\
\text { examination }\end{array}$ & Finland & $\begin{array}{c}\text { The citizen city } \\
\text { of tampere }\end{array}$ & $\begin{array}{l}\text { This paper makes two } \\
\text { contributions: first, by extending } \\
\text { the analysis of knowledge } \\
\text { management strategy to public } \\
\text { management, and second, by } \\
\text { providing a practical illustration } \\
\text { of the development process, } \\
\text { where knowledge was put into } \\
\text { prime focus in developing public } \\
\text { management. The study at hand } \\
\text { applied an approach in an attempt } \\
\text { to understand the various } \\
\text { management aspects that must be } \\
\text { taken into account when } \\
\text { constructing a knowledge } \\
\text { management strategy in local } \\
\text { government. Thus, this paper } \\
\text { links the theoretical discussions } \\
\text { on knowledge and public } \\
\text { management and provides a new } \\
\text { understanding of public } \\
\text { knowledge management }\end{array}$ \\
\hline
\end{tabular}




\section{Future Research}

Based on some literature studies conducted in this research, there were 7 (seven) future research strategies that can be determine such as :

a) Further research of this study can be directed to the validation of the theoretical model in real government environment in order to get the evaluation and judgment.

b) In the future this research can be develop using another knowledge management assessment method and with a large sample respondent also more than one case study.

c) Future research this knowledge management process can be generates as general knowledge management process in Indonesian government institution

d) Future research can be expanded for the Indonesian government institution or NGOs and construct with another research methods

e) Further study is expected to continue to analyze or implement the next phases which are the knowledge development, then knowledge management implementation, and lastly knowledge management evaluation. The evaluation performed at each of iteration is fundamental so that it can identify what corrective action should be taken to increase employee acceptance in performing knowledge management initiatives and to measure company's performance after knowledge management initiatives is conducted.

f) Future research can be expanded to create the readiness adoption level of NUSANTARA model and the measurement instrument and compose a guideline book to interpret the knowledge management implementation step by step.

g) The issue of knowledge management in the public sector offers several avenues for future research. One of the most interesting and important questions relates to the implementation and operationalization of knowledge management as a part of the general management system and the creation of a culture of knowledge-based management. adopting an action-oriented approach made it possible to study the process of developing strategic knowledge management in a specific social and organizational setting.

According to the some further research view, it is clearly that challenges of knowledge management strategy in local government become the practical recommendations and key elements of a knowledge management strategy in the public sector can be condensed On Indonesian Local Legislative Council.

\section{References}

[1] Dalkir K. Knowledge Management in Theory and Practice. Oxford. UK: Eselvier Butterworth-Heinemann; 2005.

[2] Bercerra-Fernandez I, Sabherwal R. Knowledge Management System and Process. Prentice Hall, editor. Upper Saddle River, New Jersey: M.E. Sharp, Inc.; 2004.

[3] Peraturan Menteri Negara Pendayagunaan Aparatur Negara Dan Reformasi Birokrasi Nomor 14 Tahun 2011 Tentang Pedoman Pelaksanaan Program Manajemen Pengetahuan (Knowledge Management)

[4] Dana Indra Sensuse, Lukman. Knowledge Management Model and Strategy of Genetic Resources and Traditional Knowledge in Indonesia. IJCSI International Journal of Computer Science Issues, Vol. 9, Issue 2, No 2, March 2012

[5] Elin Cahyaningsih, Dieny Sukmiati, Nur Chasanah, Dana Indra Sensuse. Defining Knowledge Management Strategy In Indonesian Government: Case Study Head Office Of Badan Kepegawaian Negara. Journal Of Information Systems, Volume 9, Issue 2, October 2013

[6] Albert Yosua, Jann Hidajat Tjakraatmadja. Assessment and Planning of Knowledge Management at PT Dirgantara Indonesia (Persero). Procedia - Social and Behavioral Sciences 169 ( 2015 ) 109 - 124

[7] Romi Satria Wahono. A Systematic Literature Review of Software Defect Prediction: Research Trends, Datasets, Methods and Frameworks. Journal of Software Engineering, Vol. 1, No. 1, April 2015

[8] Dana Indra Sensusea, Elin Cahyaningsiha, Wahyu Catur Wibowo. Identifying Knowledge Management Process Of Indonesian Government Human Capital Management Using Analytical Hierarchy Process And Pearson Correlation Analysis. Procedia Computer Science 72 ( 2015 ) 233 - 243

[9] Dana Indra Sensuse, Wahyu Catur Wibowo, Elin Cahyaningsih. Indonesian Government Knowledge Management Model: A Theoretical Model, Information Resources Management Journal Volume 29 Issue 1, January-March 2016

[10] Elin Cahyaningsih, Dana Indra Sensusea, Handrie Noprisson. Multi Methods For Knowledge Management Strategy Roadmap Of Government Human Capital Management. Procedia Computer Science 124 (2017) 496-503

[11] Elin Cahyaningsih, Dana Indra Sensuse, Aniati Murni Arymurthy, Wahyu Catur Wibowo. NUSANTARA : A New Model Of Knowledge Management In Government Human Capital Management. Procedia Computer Science 124 (2017) 61-68

[12] Harri Laihonen, Sari Mäntylä, (2018) "Strategic knowledge management and evolving local government", 
Journal of Knowledge Management, Vol. 22 Issue: 1, pp.219-234 (C) Emerald Publishing Limited, ISSN $1367-3270$

[13] Assistriadi Widjiseno, Joko Triono. Design And Development Of APBD (Indonesian Local Government District Annual Budget) Information Systems Analysis Application. International Journal Of Advanced Research In Computer Science Volume 9, No. 4, July - August 2018 ISSN No. 0976-5697

[14] Ana Isabel Torres, Silvana Santos Ferraz, Helena Santos-Rodrigues, (2018) "The impact of knowledge management factors in organizational sustainable competitive advantage", Journal of Intellectual Capital, Vol. 19 Issue: 2, pp.453-472 (C) Emerald Publishing Limited 1469-1930 DOI 10.1108/JIC-12-2016-0143.

[15] Mostafa Al-Emran, Vitaliy Mezhuye, Adzhar Kamaludin, Khaled Shaalan. "The impact of knowledge management processes on information systems: A systematic review", International Journal of Information Management 43 (2018) 173-187 